\title{
SOSIALISASI MANFAAT IPTEK NUKLIR DI DESA BAH DAMAR KECAMATAN DOLOK MARAWAN KABUPATEN SERDANG BEDAGAI
}

\author{
Sari Novalianda ${ }^{1^{*}}$, Andri Ramadhan ${ }^{2}$, Panangian Mahadi Sihombing ${ }^{3}$ \\ ${ }^{1,3}$ Teknik Elektro, Fakultas Teknik, Universitas Al-Azhar, Jl. Pintu Air IV No.214, Kwala Bekala, \\ Kec. Medan Johor, Kota Medan, Sumatera Utara 20143 \\ ${ }^{2}$ Teknik Mesin, Fakultas Teknik, Universitas Al-Azhar, Jl. Pintu Air IV No.214, Kwala Bekala, Kec. \\ Medan Johor, Kota Medan, Sumatera Utara 20143 \\ *sari_novalianda@yahoo.com
}

\begin{abstract}
ABSTRAK. Nuklir oleh sebagian orang masih di identikkan dengan bom, sesuatu hal yang bersifat negatif dan berbahaya. Padahal teknologi nuklir memiliki banyak sisi positif dalam penggunaannya. Keberadaan IPTEK nuklir banyak memberikan manfaat besar, baik dibidang energi yang ramah lingkungan dengan tidak menghasilkan polusi udara dan efek rumah kaca, dibidang pertanian dapat menghasilkan jenis varietas unggul yaitu Sorgum, Beras dan Jagung, dibidang pengawetan makanan, nuklir dapat membuat makanan tersebut bertahan lama dan dibidang kesehatan energi nuklir dapat digunakan dalam pengobatan kanker. Metode yang diberikan dengan cara ceramah dan diskusi serta memberikan video penerapan IPTEK nuklir yang telah diproduksi secara nasional oleh badan riset BATAN. Dengan berbagai macam manfaat nuklir ini diharapkan masyarakat setempat dapat menerima keberadaan energi nuklir dan memanfaatkannya.
\end{abstract}

Kata kunci: BATAN, IPTEK Nuklir

ABSTRACT. Nuclear, by some people, is still identified with the bomb, something that is negative and dangerous. However, nuclear IPTEK has many positive sides in its use. The existence of atomic technology provides many great benefits, both in the field of environmentally friendly energy by not producing air pollution and the greenhouse effect, in agriculture it can have superior varieties, namely Sorghum, Rice and Corn, in the field of food preservation, nuclear can make the food last longer, and In the field of health, atomic energy can be used in the treatment of cancer. The method is using lectures and discussions and providing videos on the application of nuclear science and technology, which have been produced nationally by the BATAN research agency. With these various kinds of atomic benefits, it is hoped that the local community will accept the existence of nuclear energy and use it.

Keywords: BATAN, IPTEK, Nuclear

Terima 20 Januari 2022 Terima dan di revisi 22 Januari 2022 Disetujui 26 Januari 2022

\section{PENDAHULUAN}

Desa Bah Damar Kecamatan Dolok Marawan Kabupaten Serdang Bedagai memiliki luas 190 HA dengan jumlah penduduk sekitar 701 jiwa dengan mayoritas penduduknya bekerja di bidang pertanian terutama menanam tanaman umbi-umbian dan pepaya. Nuklir oleh sebagian orang masih di identikkan dengan bom, sesuatu hal yang bersifat negatif dan berbahaya. Padahal teknologi nuklir memiliki banyak sisi positif dalam penggunaannya. Keberadaan teknologi nuklir banyak memberikan manfaat besar, salah satunya adalah di bidang energi sebagai salah satu bentuk energi alternatif . Menurut Catatan World Nuclear Assosiation per Januari 2021 terdapat 32 negara yang reaktor nuklirnya masih tetap beroperasi dan 17 negara dalam tahap perencanaan pembangunan (IAEA, 2014). Jumlah terebut akan terus bertambah di masa yang akan datang, sebagai konsekuensi bertambahnya kebutuhan energi, serta semakin timbulnya kepedulian masyarakat akan lingkungan, akibat pencemaran udara yang diakibatkan oleh penggunaan bahan bakar batubara, minyak bumi dan gas dalam pembangkit listrik (Kelly, 2014). Energi 
nuklir merupakan salah satu bagian dari bentuk reneweble energy atau energi baru dan terbarukan di Indonesia. Pengembangan energi nuklir di Indonesia didasarkan pada PP Nomor 79 tahun 2014 tentang kebijakan energi nasional dan PP Nomor 2 Tahun 2014 tentang perizinan instalasi nuklir dan pemanfaatan bahan nuklir. Energi nuklir memiliki potensi untuk bisa dikembangkan di Indonesia. Secara geologi seperempat daratan Indonesia mengandung deposit mineral radioaktif terutama Uranium dan Thorium. Pemetaan daerah yang berpotensi Uranium dan Thorium berada di Bangka Belitung, pulau Sulawesi, Sumatera dan di Kalimantan salah satunya di wilayah Kalan (Novalianda, 2020).Manfaat lainnya dari penggunaan teknologi nuklir banyak digunakan, dibidang pertanian, dunia industri, pengawetan makanan, dan dibidang kesehatan yang ke semuanya memberikan kontribusi besar dalam kehidupan kita (BATAN, 2020) .Oleh karena itu menjadi sangat penting bagi kita untuk mengetahui manfaat besar dari penggunaan teknologi nuklir yang berkembang saat ini sehingga persepsi negatif akan keberadaan nuklir dapat di hilangkan menjadi suatu hal yang positif yaitu sebagai sebuah pengetahuan dan riset yang terus berkembang dan bermanfaat.

\section{METODE}

Metode pelaksanaan yang dilakukan adalah dengan melakukan sosialisasi melalui kegiatan ceramah/diskusi yang awalnya diperkenalkan terlebih dahulu apa itu nuklir, perbedaan antara Nuklir dan Bom, kemudian di paparkan berbagai IPTEKS nuklir yang telah di manfaatkan bagi lingkungan, industri, pertanian dan bidang kesehatan. Kemudian setelah diadakan paparan, ditampilkan video IPTEK nuklir yang telah diproduksi bangsa Indonesia oleh salah satu badan riset nasional yaitu BATAN.

\section{HASIL DAN PEMBAHASAN}

Kegiatan sosialisasi IPTEK nuklir melalui kegiatan ceramah dan diskusi yang melibatkan masyarakat desa Bah Damar yang pada awalnya masyarakat setempat masih berasumsi negatif bahkan menolak akan adanya nuklir karena masih beranggapan bahwa nuklir itu identik bahkan sama dengan bom. Setelah di berikan pemahaman dan informasi yang jelas tentang berbagai manfaat IPTEK nuklir yang sangat besar, dimana dari segi energi, nuklir merupakan sumber energi listrik yang ramah lingkungan bebas dari pencemaran udara dan efek rumah kaca dibandingkan dengan sumber energi listrik fosil yang menghasilkan $\mathrm{CO} 2$, SO2 dan lainnya (Novalianda S. A., 2020). Dibidang lainnya seperti pertanian, IPTEK nuklir sangat berguna untuk menghasilkan bibit unggul Padi/beras, jagung dari segi umur panennya dan menghasilkan varietas yang unggul, dibidang proses pengawetan makanan yang dilakukan dengan bantuan energi nuklir dapat membuat makanan awet dalam jangka waktu yang lama tanpa mengurangi gizi dari makanan tersebut, dibidang kesehatan IPTEK nuklir sangat membantu dalam produksi isotop yang dapat digunakan untuk mengobati penyakit kanker (BATAN, 2020).

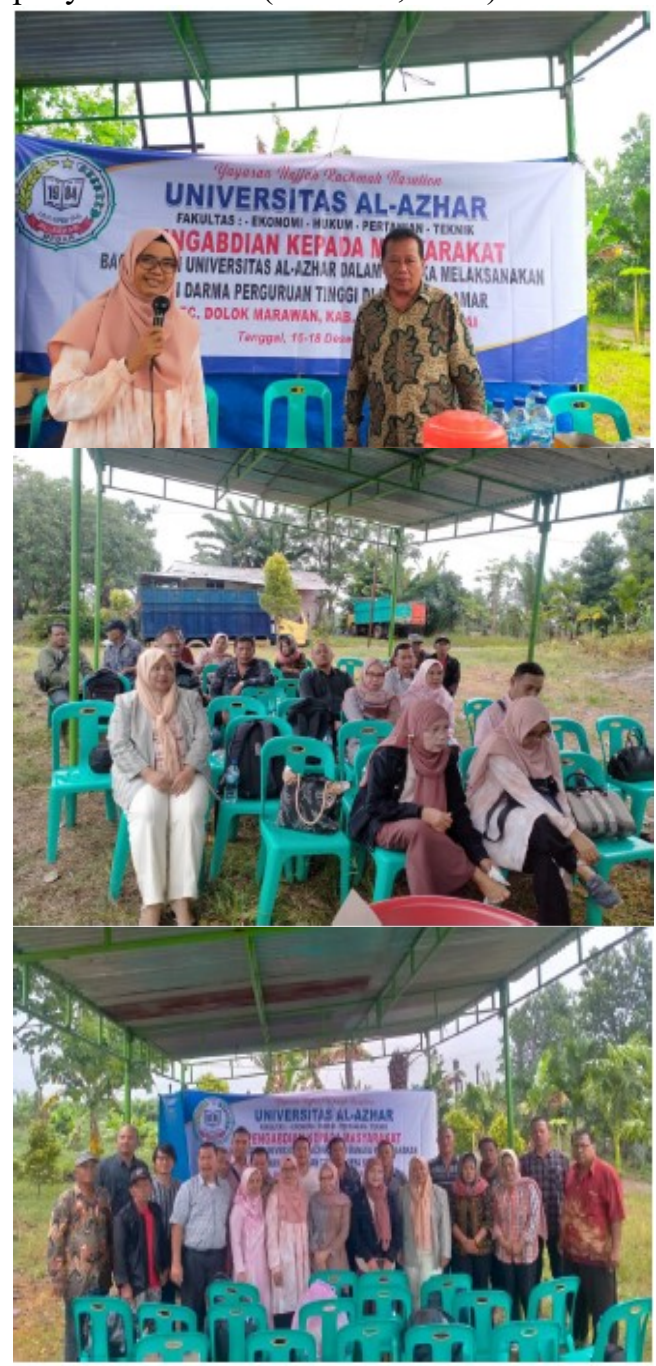

Gambar 1 Kegiatan Ceramah dan Diskusi IPTEK Nuklir 


\section{SIMPULAN}

Melalui kegiatan sosialisasi IPTEK nuklir ini, masyarakat Bah Damar Kecamatan Dolok Marawan Kabupaten Serdang Bedagai Mendapatkan pengetahuan baru dan informasi yang akurat terkait manfaat dari IPTEK nuklir bagi lingkungan dan dibidang lainnya yang dapat mengubah stigma negatif tentang nuklir

\section{UCAPAN TERIMAKASIH}

Terima kasih kami ucapkan kepada Ibu rektor Universitas Al Azhar, yang telah mendukung acara ini sehingga berjalan dengan mulus. Begitu juga kepada rekan rekan sejawat yang tergabung dalam satu TIM besar pengabdian kepada Masyarakat. Tidak lupa juga ucapan terima kasih kepada Bapak Anggota Dewan yang telah mendukung dan memfasilitasi acara ini, Terimakasih kami ucapkan Pejabat Pemerintahan, yang telah berkenan untuk hadir dalam acara tersebut. Terima kasih kami ucapkan Bapak Kepala desa dan perangkatnya, serta kepada seluruh masyarakat masyarakat Desa Bah Damar Kecamatan Dolok Marawan Kabupaten Serdang Bedagai. Yang telah ikut mendukung dan berpartisipasi dalam acara ini sehingga acara ini berjalan lancar, sesuai dengan yang diharapkan.

\section{DAFTAR PUSTAKA}

BATAN. (2020, Oktober). Inilah Pemanfaatan Nuklir Di Bidang Pertanian dan Industri.

BATAN. (2020, November). Inovasi Teknologi Nuklir telah Dimanfaatkan di Bidang Industri dan Kesehatan.

IAEA. (2014). International Status and Prospects for Nuclear Power 2014.

Kelly, E. J. (2014). Generation IV International Forum: A Decade of Progress Through Iinternational Cooperation. Elsevier, 240-246.

Novalianda, S. A. (2020). Perhitungan Burnup Desain Reaktor GFR berbasis bahan bakar Uranium Nitride. Jurnal Penelitian Sains, 50-54.

Novalianda, S. d. (2020). Pengaruh Perubahan Fraksi Volume Terhadap Kekritisan Desain Gas-Cooled Fast Reactor Berbahan Bakar Uranium Nitride. Jurnal Fisika Unand (JFU), 450-456. 